\title{
Extraction \& Processing Division: 2013 in Review
}

\author{
Adrian Deneys, Mark Schlesinger, Boyd Davis, and Tom Battle
}

\section{ABOUT THE EPD}

The TMS Extraction \& Processing Division (EPD) has more than 830 members, most of whom reside outside of the United States. The EPD, one of five technical divisions in TMS, focuses on the sustainable extraction and processing of minerals and metals from mined ores, concentrates, and recycled materials using pyrometallurgical, hydrometallurgical, and/or electrochemical processes, emphasizing the technical, engineering, environmental, and economic principles of these processes. The EPD also addresses further processing of non-ferrous metals such as copper, nickel, cobalt, precious metals, lead, zinc, and tin and their products. Among the techniques employed to convert those materials into finished and semifinished products are refining, purification, alloying, solidification, thermomechanical treatment, and surface coating.

The EPD is organized into six technical committees and a council of supporting positions to accomplish its objectives. The technical committees are Energy (joint with the Light Metals Division [LMD]), Hydrometallurgy and Electrometallurgy, Materials Characterization, Process Technology and Modeling (joint with the Materials Processing \& Manufacturing Division [MPMD]), Pyrometallurgy, and Recycling (joint with the LMD).

\section{PROGRAMMING AND PUBLICATION}

The EPD seeks to support efforts brought forward by members that provide benefits to the profession.
One of the primary areas of support for its members is in organizing symposia for the TMS Annual Meeting. At the TMS 2013 Annual Meeting \& Exhibition (TMS2013), the EPD sponsored or co-sponsored 10 symposia with 373 presentations, 292 of which were published in proceedings. A summary of these symposia and lead organizers is given in Table I. We appreciate the organizers for their efforts and time spent making these events a success.

Also at TMS2013, the EPD encouraged professional development opportunities to the community by sponsoring three short courses:

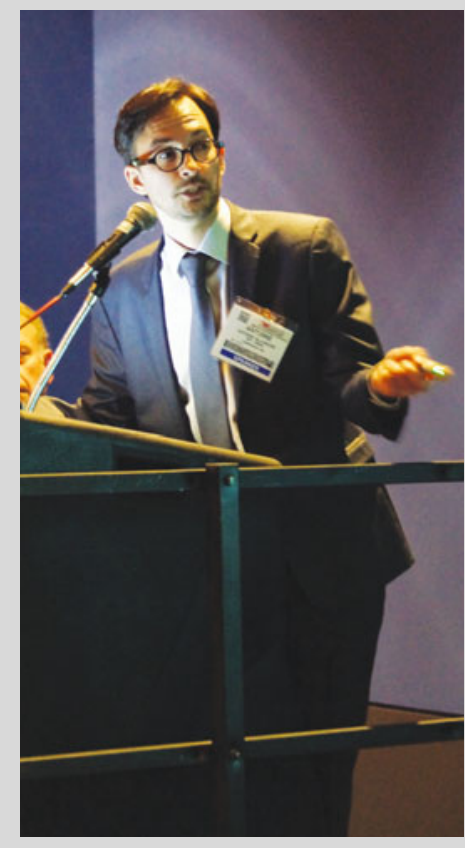

Antoine Allanore presents the EPD Distinguished Lecture at the TMS 2013 Annual Meeting \& Exhibition, on behalf of Donald Sadoway.
- Extractive Metallurgy of Nickel and Cobalt, a two-day short course, conducted by Michael Moats, Bill Davenport, Maurice Solar, Tim Robinson, Bruce Love, Indie Mihaylov, Ram Ramachandran, and Norbert Piret

- Managing Technical and Financial Risk in a New Technology, a one-day short course, conducted by Phillip Mackey and Mark Kennedy

- Modeling Electrodeposition, a one-day short course, conducted by Adam C. Powell

The nickel-cobalt short course was held in conjunction with the International Nickel-Cobalt Symposium (Ni-Co 2013). We thank the organizers and presenters for their efforts to present these short courses.

To further encourage the sharing of knowledge in the mining and minerals community during 2013, the EPD continued to support the OneMine digital library. The most recent TMS addition to the OneMine library includes more than 6,000 pages from a variety of sources, including proceedings volumes such as Copper '99, Sulfide Smelting 2002, and three Rare Earths volumes.

OneMine is a joint effort among several professional societies to create a single resource for mining and minerals, and includes technical documents, conference papers, and more. TMS members can subscribe to OneMine at a discounted rate, thanks to the society's contributions to the library. Details are in the Members Only section of the TMS website, under "Membership Add-Ons." 
Table I.TMS2013 Symposia Sponsored or Co-sponsored by the EPD

\begin{tabular}{|c|c|c|c|}
\hline Symposium Name & $\begin{array}{l}\text { Division } \\
\text { Sponsors }\end{array}$ & Committee Sponsors & Organizer(s) \\
\hline $\begin{array}{l}\text { 4th International } \\
\text { Symposium on } \\
\text { High-Temperature } \\
\text { Metallurgical } \\
\text { Processing }\end{array}$ & EPD & $\begin{array}{l}\text { Energy; Materials } \\
\text { Characterization; Pyrometallurgy }\end{array}$ & $\begin{array}{l}\text { - Tao Jiang, Central South University } \\
\text { - Jiann-Yang Hwang, Michigan Technological University } \\
\text { - } \quad \text { Phillip Mackey, Consultant } \\
\text { - Onuralp Yücel, ITU } \\
\text { - Guifeng Zhou, Wuhan Iron and Steel }\end{array}$ \\
\hline Battery Recycling & EPD, LMD & $\begin{array}{l}\text { Energy Conversion and Storage; } \\
\text { Recycling and Environmental } \\
\text { Technologies }\end{array}$ & $\begin{array}{l}\text { - Gregory K. Krumdick, Argonne National Laboratory } \\
\text { - Linda Gaines, Argonne National Laboratory } \\
\text { - John Sullivan, Argonne National Laboratory }\end{array}$ \\
\hline $\begin{array}{l}\text { Characterization of } \\
\text { Minerals, Metals, and } \\
\text { Materials } 2013\end{array}$ & EPD & Materials Characterization & $\begin{array}{l}\text { - Jiann-Yang Hwang, Michigan Technological University } \\
\text { - } \quad \text { Chen-Guang Bai, Chongqing University } \\
\text { - John Carpenter, Los Alamos National Laboratory } \\
\text { - } \quad \text { Shadia J Ikhmayies, Al Isra University } \\
\text { - } \quad \text { Bowen Li, Michigan Technological University } \\
\text { - } \quad \text { Mingming Zhang, ArcelorMittal Global R\&D } \\
\text { - Sergio N. Monteiro, State University of North Rio de Janeiro } \\
\text { - Zhiwei Peng, Michigan Technological University }\end{array}$ \\
\hline $\begin{array}{l}\text { Energy Technologies } \\
\text { and Carbon Dioxide } \\
\text { Management }\end{array}$ & EPD, LMD & Energy; Education & $\begin{array}{l}\text { - Soobhankar Pati, MOxST Inc. } \\
\text { - Animesh Jha, University of Leeds } \\
\text { - Jaroslaw Drelich, Michigan Technological University } \\
\text { - Neale R. Neelameggham, Ind LLC } \\
\text { - Cong Wang, Northwestern University } \\
\text { - Leon H. Prentice, CSIRO }\end{array}$ \\
\hline $\begin{array}{l}\text { High Temperature } \\
\text { Electrochemistry }\end{array}$ & EPD & Pyrometallurgy & $\begin{array}{l}\text { - Prabhat Tripathy, Idaho National Laboratory } \\
\text { - Guy Fredrickson, Idaho National Laboratory }\end{array}$ \\
\hline $\begin{array}{l}\text { Materials Processing } \\
\text { Fundamentals }\end{array}$ & EPD & $\begin{array}{l}\text { Process Technology and } \\
\text { Modeling }\end{array}$ & $\begin{array}{l}\text { - Lifeng Zhang, University of Science and Technology Beijing } \\
\text { - Antoine Allanore, Massachusetts Institute of Technology } \\
\text { - Cong Wang, Northwestern University } \\
\text { - James Yurko, Materion Brush Beryllium and Composites } \\
\text { - Justin Mandel Crapps, ExxonMobil }\end{array}$ \\
\hline Ni-Co 2013 & EPD & $\begin{array}{l}\text { Hydrometallurgy and } \\
\text { Electrometallurgy; Pyrometallurgy }\end{array}$ & - Thomas Battle, Midrex Technologies \\
\hline $\begin{array}{l}\text { Production, Refining } \\
\text { and Recycling of Rare } \\
\text { Earth Metals }\end{array}$ & $\begin{array}{l}\text { Electronic, } \\
\text { Magnetic } \\
\text { \& Photonic } \\
\text { Materials } \\
\text { Division, } \\
\text { EPD, } \\
\text { MPMD }\end{array}$ & $\begin{array}{l}\text { Magnetic Materials; Process } \\
\text { Technology and Modeling }\end{array}$ & $\begin{array}{l}\text { - Lifeng Zhang, University of Science and Technology Beijing } \\
\text { - Oliver Gutfleisch, IFW Dresden } \\
\text { - Jeffrey S. Spangenberger, Argonne National Laboratory }\end{array}$ \\
\hline $\begin{array}{l}\text { REWAS 2013: Enabling } \\
\text { Materials Resource } \\
\text { Sustainability }\end{array}$ & EPD & $\begin{array}{l}\text { Recycling and Environmental } \\
\text { Technologies; Education; } \\
\text { Materials and Society }\end{array}$ & $\begin{array}{l}\text { - } \text { Christina Meskers, Umicore Precious Metals Refining } \\
\text { - } \text { Anne Kvithyld, SINTEF } \\
\text { - } \text { Markus A. Reuter, Outotec Oyj } \\
\text { - } \text { Mark Schlesinger, Missouri University of Science and } \\
\text { - Technology } \\
\text { - Gregory K. Krumdick, Argonne National Laboratory } \\
\text { - Gabrielle Gaustad, Rochester Institute of Technology } \\
\text { - } \text { Diana A. Lados, Worcester Polytechnic Institute } \\
\text { - } \text { Brajendra Mishra, Colorado School of Mines } \\
\text { - Jeffrey S. Spangenberger, Argonne National Laboratory }\end{array}$ \\
\hline Solar Cell Silicon & EPD, LMD & $\begin{array}{l}\text { Energy Conversion and Storage; } \\
\text { Recycling and Environmental } \\
\text { Technologies }\end{array}$ & $\begin{array}{l}\text { - Gabriella Tranell, Norwegian University of Science and } \\
\text { Technology } \\
\text { - Arjan Ciftja, SINTEF } \\
\text { - Shadia Jamil Ikhmayies, Al Isra University } \\
\text { - Yulia Meteleva-Fischer, Materials innovation institute (M2i) }\end{array}$ \\
\hline
\end{tabular}




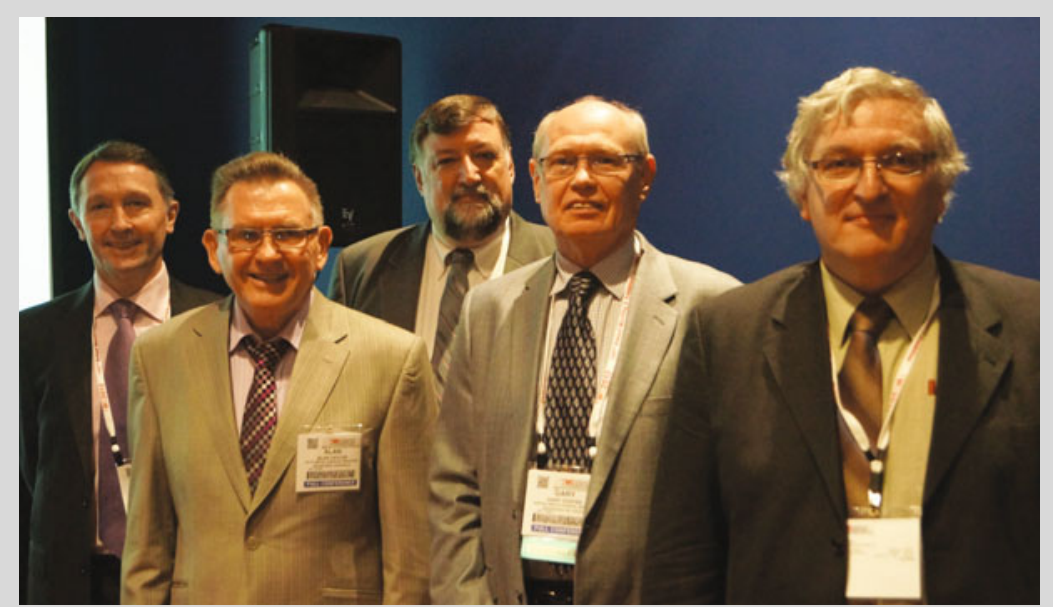

Speaking at the opening session of the 2013 International Nickel-Cobalt Symposium were (L-R): David Weight, Cobalt Development Institute; Alan Taylor, ALTA Metallurgical Services; Tom Battle, symposium organizer; Gary Coates, Nickel Institute; Cesar "Joe" Ferron, Molycorp Minerals Canada.

\section{AWARDS}

The EPD also sponsors several awards and scholarships each year. The awards and scholarships were presented at the joint EPD/MPMD luncheon at TMS2013. In 2013, the EPD awards included:

- EPD Distinguished Lecturer: Donald Sadoway, John F. Elliott Professor of Materials Chemistry, Massachusetts Institute of Technology (MIT). His lecture topic was "Towards Sustainable Metal Production by Molten Oxide Electrolysis."

- EPD Distinguished Service Award: Adam Powell, Infinium Metals

- EPD Technology Award: Elizabeth Sterling, University of British Columbia; Jonathan Stolk, Olin College of Engineering; Lauren Hafford, Vestas; and Michael Gross, Bucknell University, for "Sodium Borohydride Reduction of Aqueous Silver-Iron-Nickel Solutions: A Chemical Route to Synthesis of Low Thermal Expansion-High Conductivity Ag-Invar Alloys," published in Metallurgical and Materials Transactions $A$

- EPD Science Award: Peter Hayes, University of Queensland, for "Stability
Criteria for Product

Microstructures Formed on Gaseous Reduction of Solid Metal Oxides," published in Metallurgical and Materials Transactions $B$

- EPD Young Leader Professional Development Award: Hojong Kim, MIT; Jonghyun Lee, Tufts University; Thomas Wynn, Los Alamos National Laboratory; and Jan deBakker, BBA Incorporated

- EPD Scholarship: Jordan Rutledge, Colorado School of Mines

- AIME James Douglas Gold Medal Award: Patrick Taylor, Colorado School of Mines

- EPD Luncheon Lecturer: Maurits Van Camp, Director of Competency Platform for Recycling \& Extraction, Umicore, Olen, Belgium. His lecture topic was "Sustainability: A Paradigm Shift for Metals?"

At the TMS society level, Leon Prentice of CSIRO in Australia received the 2013 Vittorio de Nora Prize for Environmental Improvements in Metallurgical Industries. Congratulations to all of the EPD award winners.

The EPD also hosted organizational meetings for the following special symposia or organizations:

- Copper 2013 Organizing Committee meeting, hosted by

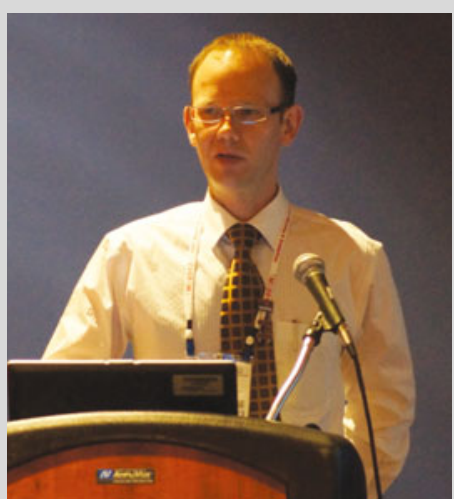

Leon Prentice, winner of the 2013 Vittorio de Nora Prize, presented "It Is Rocket Science: The Engineering Impact of Carbothermal Magnesium Technology" as his lecture topic.

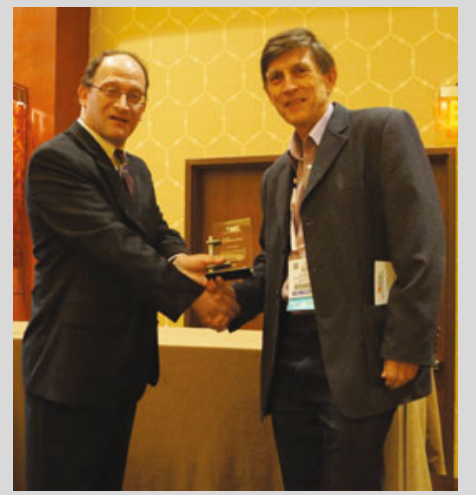

Peter Hayes, right, receives the EPD Science Award from division ViceChair Mark Schlesinger.

\section{Michael Moats}

- Lead Zinc 2015 Organizing Committee meeting, hosted by Andreas Sigmund

- 2014 Robertson Symposium Organizing Committee meeting, hosted by Phillip Mackey

- North American Extractive Metallurgy Council meeting, hosted by Tom Battle, with the Society for Mining, Metallurgy \& Exploration and the Metallurgy and Materials Society of the Canadian Institute of Mining, Metallurgy, and Petroleum

Adrian Deneys, Business Development Manager, Praxair Inc., San Ramon, CA. Mark Schlesinger, Professor of Metallurgical Engineering, Missouri University of Science and Technology, Rolla, MO. Boyd Davis, Adjunct Professor, Queen's University, Kingston, ON, Canada. Tom Battle, Senior Metallurgist, Midrex Technologies, Pineville, NC. 